\title{
Peningastefnunefnd í sjö ár
}

\author{
Karen Áslaug Vignisdóttir ${ }^{1}$
}

\begin{abstract}
Ágrip
Peningastefnunefnd Seðlabanka Íslands hefur starfað í meira en sjö ár. Pegar umgjörð peningamála var breytt með lagabreytingu árið 2009 sem kvað á um skipan peningastefnunefndarinnar var alpjóðleg reynsla af tilhögun ákvörðunartöku í peningamálum höfð til hliðsjónar. Jafnframt voru gerðar breytingar er miðuðu að auknu gagnsæi og trúverðugleika peningastefnunnar. Athugun á atkvæðagreiðslum peningastefnunefndar á tímabilinu 2009-2015 leiðir í ljós að ólík sjónarmið hafi verið til staðar innan nefndarinnar. Ekki náðist full samstaða í hátt í helmingi atkvæðagreiðslna, í priðjungi tilvika kaus einn nefndarmaður gegn meirihlutanum og í tæplega sjöttungi tilvika voru tveir nefndarmenn í minnihluta. Pegar um er að ræða ágreining í nefndinni samanstendur meirihlutinn oftar af bæði innri og ytri nefndarmönnum heldur en eingöngu innri nefndarmönnum. Samsetning minnihlutans á vaxtaákvörðunarfundum hefur jafnframt verið nokkuð breytileg á tímabilinu. Atkvæðaskipting peningastefnunefndar virðist vera svipuð pví sem tíðkast í nágrannalöndum okkar sem eru með svipað fyrirkomulag. Breytt tilhögun ákvarðanatöku í peningamálum virðist hafa skilað árangri. Pjóðarbúskapurinn hefur náð sér á strik í kjölfar fjármálakreppunnar og verið í betra jafnvægi. Verðbólga hefur verið undir verðbólgumarkmiði bankans um tveggja og hálfs árs skeið og langtímaverðbólguvæntingar hafa pokast niður á við. Ætla má að árangur peningastefnunnar undanfarin ár hafi átt pátt í að skapa peim traustari kjölfestu en áður. Aðrir ólíkir pættir hafa pó einnig gegnt mikilvægu hlutverki í efnahagsbata undanfarinna ára.
\end{abstract}

\begin{abstract}
The Central Bank of Iceland Monetary Policy Committee (MPC) has been active for more than seven years. When Iceland's monetary framework was revised with a 2009 statutory amendment providing for the appointment of a monetary policy committee, consideration was given to international precedents on best practice for monetary decision-making. Other changes focused on increased transparency and credibility of monetary policy. A study of the MPC's voting patterns during the period 2009-2015 reveals divergent points of view among Committee members. Nearly half of the MPC's decisions were not unanimous: in one-third of instances, one member voted against the majority, and in nearly one-seventh of instances, two members voted against the majority. When there has been a disputed decision, the majority has consisted more often of both internal and external members than of internal members only.

${ }^{1}$ Höfundur er sérfræðingur á hagfræði- og peningastefnusviði Seðlabanka Íslands. Skoðanir sem koma fram í greininni eru höfundar og ber ekki að túlka sem skoðanir Seðlabanka Íslands. Höfundur pakkar Ásgeiri Daníelssyni, Rannveigu Sigurðardóttur, Porvarði Tjörva Ólafssyni og nefndarmönnum peningastefnunefndar fyrir gagnlegar ábendingar.
\end{abstract}

This work is licensed under a Creative Commons Attribution 4.0 License. 
The composition of the minority has also varied somewhat over the period in question. The voting patterns of the Icelandic MPC appear to be similar to those in neighbouring countries with a similar monetary policy framework. The revision of the framework for monetary decision-making appears to have been a change for the better. The Icelandic economy has recovered from the financial crisis and appears to be better balanced than before. Inflation has been below the Central Bank's inflation target for about two-and-a-half years, and long-term inflation expectations have subsided. It can be assumed that the success of monetary policy in recent years has played a role in anchoring expectations more firmly. Other factors have also played an important part in the recent economic recovery, however.

JEL flokkun: E58, D71, D72, D78

Lykilorð: seðlabankar, peningastefna, peningastefnunefnd, atkvæðagreiðslur

„Peningastefnunefnd í sjö ár", eftir Karen Áslaugu Vignisdóttur var áður birt í riti Seðlabanka Íslands, Efnahagsmál $\quad n r . \quad 8, \quad$ sjá nánari http://www.sedlabanki.is/utgefid-efni/rit-ogskyrslur/rit/2016/09/02/Nytt-rit-um-starf-peningastefnunefndar-i-sjo-ar/. 


\section{Inngangur}

Miklar breytingar hafa orðið á umgjörð peningamála í heiminum undanfarna áratugi og seðlabönkum par sem ákvarðanir í peningamálum eru teknar af fjölskipuðum peningastefnunefndum fremur en einum einstaklingi eða fámennri bankastjórn hefur fjölgað. Rannsóknir benda til pess að slíkt fyrirkomulag henti betur við ákvörðunartöku í peningamálum. Ákvarðanir hafa tilhneigingu til að vera betur ígrundaðar pegar nefnd skipuð hópi sérfræðinga sameinar krafta sína, pekkingu og ólíka reynslu í pví skyni að komast að sem bestri niðurstöðu með gagnrýnum og uppbyggilegum skoðanaskiptum. Sé bakgrunni ákvarðanatökunnar miðlað til almennings með tilkynningum og birtingu fundargerða auðveldar pað jafnframt miðlun peningastefnunnar. En hvers konar uppbygging peningastefnunefnda hentar best? Pær eru ólíkar að gerð, t.d. varðandi fyrirkomulag ákvörðunartöku, stærð og samsetningu nefndarinnar og stöðu seðlabankastjóra innan hennar sem formanns.

Breytingarnar sem gerðar voru snemma árs 2009 komu í kjölfar fjármálaáfallsins haustið 2008 og tóku mið af reynslunni í aðdraganda kreppunnar. ${ }^{2}$ Tiltölulega slakur árangur í viðureigninni við verðbólgu hér á landi í samanburði við önnur próuð lönd og reynslan af fjármálakreppunni, bæði hér á landi og erlendis, benti til pess að styrkja pyrfti framkvæmd peningastefnunnar og efnahagsstefnunnar almennt, auk regluverks á fjármálamarkaði. Lagabreytingarnar fólu einnig í sér kröfu um aukið gagnsæi og bætta starfshætti.

Breytt tilhögun ákvarðanatöku í peningamálum virðist hafa skilað árangri. Próun efnahagsmála á árunum 2009-2015 hefur verið jákvæð að mörgu leyti. Tekist hefur að endurheimta stöðugleika og renna stoðum undir langvarandi hagvaxtarskeið í kjölfar efnahagssamdráttarins sem fylgdi fjármálakreppunni. Verðbólga hefur almennt haldist lítil, atvinnuleysi verið lítið, pjóðhagslegur sparnaður aukist og viðskiptaafgangur verið töluverður. Aðrir ólíkir pættir hafa pó einnig gegnt mikilvægu hlutverki í efnahagsbata undanfarinna ára. Höft á fjármagnsflutninga sem komið var á í lok ársins 2008 skiptu einnig töluverðu máli í að skapa svigrúm til að nauðsynleg aðlögun pjóðarbúsins gæti átt sér stað.

Núverandi fyrirkomulag hefur verið við lýði í ríflega sjö ár. Fyrir liggja gögn um atkvæðagreiðslur peningastefnunefndar fyrir tímabilið 2009-2015 (sjá Ársskýrslur Seðlabanka Íslands fyrir petta tímabil). Atkvæðamynstur peningastefnunefndar Seðlabanka Íslands sýnir að ólík sjónarmið hafa verið til staðar innan nefndarinnar á tímabilinu en í tæplega helmingi tilvika var ekki full samstaða um vaxtaákvörðunina. Jafnframt virðist atkvæðaskipting nefndarinnar frá pví að nefndin hóf störf hafa verið svipuð pví sem tíðkast í nágrannalöndum sem eru með sambærilegt fyrirkomulag.

Í pessari grein verður fjallað nánar um ólíkar gerðir peningastefnunefnda, samsetningu peirra og skipulag. Pá verður fjallað nánar um breytingarnar sem gerðar voru á ramma peningastefnunnar á Íslandi árið 2009 og áhrif peirra á gagnsæi og trúverðugleika hennar. Í lokin verður fjallað nánar um atkvæðagreiðslur peningastefnunefndar um vaxtaákvarðanir og skoðað hvernig atkvæði einstakra nefndarmanna hafa fallið á tímabilinu auk pess að fjalla um hvort atkvæðamynstrið sé ápekkt pví sem gerist í öðrum löndum með sambærilegt fyrirkomulag peningastefnu. ${ }^{3}$

2 Sjá frumvarp til laga um breytingar á lögum nr. 36/2001, um Seðlabanka Íslands, ásamt fylgiskjölum.

3 Efni pessarar umfjöllunar takmarkast við atkvæðagreiðslur peningastefnunefndar um vaxtaákvarðanir en nefndin tekur einnig ákvarðanir um beitingu annarra stjórntækja bankans í 


\section{Stjórn peningamála með peningastefnunefnd}

Undanfarna áratugi hefur seðlabönkum par sem ákvarðanir í peningamálum eru teknar af fjölskipaðri nefnd fremur en einum einstaklingi fjölgað. Sú próun átti sér stað á sama tíma og lögð var aukin áhersla á að seðlabankar væru sjálfstæðir, enda rökrétt krafa að ákvarðanir sjálfstæðrar stofnunar séu teknar af fjölskipuðu valdi par sem ólík sjónarmið fá að njóta sín og að gagnsæi ríki um pær ákvarðanir. Samkvæmt Maier (2010) voru meira en 80 seðlabankar í heiminum með peningastefnunefnd við stjórn peningamála í upphafi pessa áratugar og hvergi hefur pað gerst að seðlabanki hafi breytt umgjörð peningastefnunnar á pann hátt að horfið hafi verið frá fjölskipuðu ákvörðunarvaldi í fyrirkomulag par sem einn einstaklingur tekur ákvarðanir í peningamálum. Eins og Blinder (2009) rekur benda flestar rannsóknir til pess að fjölskipuð peningastefnunefnd henti betur við að taka ákvarðanir í peningamálum en einstaklingur hvort sem litið er til niðurstaðna fræðilegra rannsókna eða alpjóðlegrar reynslu. Pegar nefnd er skipuð hópi sérfræðinga með ólíkan bakgrunn og sameinar pví pekkingu og ólíka reynslu nefndarmanna í peim tilgangi að komast að sem bestri niðurstöðu virðist grundvöllur ákvarðana vera traustari. Ef ákvarðanir í peningamálum eru eingöngu á valdi einstaklings er meiri hætta á að hagsmunir og hugmyndir hans ráði ríkjum. Með pví að fela nefnd pað hlutverk að taka mikilvægar ákvarðanir við skilyrði óvissu er hægt að tryggja að aðstæður komi ekki upp par sem hugsanlegur dómgreindarbrestur eins einstaklings ráði för (sjá Qvigstad o.fl., 2013). Niðurstöður tilrauna Blinder og Morgan (2005, 2008a, b) par sem einstaklingar voru beðnir um að leysa tiltekin verkefni, m.a. að taka ákvarðanir í peningamálum með pví að nota hermilíkön, benda til pess að hópar taki betri ákvarðanir en einstaklingar. Jafnframt sýna niðurstöður peirra að pað virtist ekki vera meiri tregða (e. inertia) í ákvörðunartöku hjá hópum en hjá einum einstaklingi. Tilraunir Lombardelli, Proudman og Talbot (2005) leiða til sömu niðurstaðna um að nefndir taki betri ákvarðanir en einstaklingar einkum vegna pess að hópur einstaklinga sameinar ólíkar upplýsingar og skoðanir sínar auk pess að læra hvert af öðru.

Sibert (2006) færir hins vegar ýmis rök fyrir pví að nefndir gætu tekið verri ákvarðanir en einstaklingur. Nefndarmenn gætu t.d. hagað sér eins og laumufarpegar (e. free rider) og treyst á að aðrir í nefndinni framkvæmi alla vinnuna án pess að leggja sitt af mörkum. Að sama skapi gæti verið hætta á ákveðinni „hóphugsun“ (e. group-think) par sem nefndin reynir eftir fremsta megni að ná samstöðu um tiltekin mál en tekur ekki nægjanlegt tillit til annarra valmöguleika. Slík hjarðhegðun gæti leitt til verri ákvarðana en einstaklingur tæki.

\section{1 Ólikar gerðir peningastefnunefnda}

Oftast eru peningastefnunefndir aðgreindar eftir tvenns konar fyrirkomulagi. Annars vegar er um að ræða nefndir par sem nefndarmenn greiða atkvæði byggt á eigin mati og niðurstöður fást með meirihluta atkvæða (e. individualistic committees). Í slíkum nefndum er ekki lögð sérstök áhersla á að ná fram einingu um ákvörðunina og hver nefndarmaður er einfaldlega ábyrgur fyrir sínu atkvæði. Peningastefnunefndir Englandsbanka og Seðlabanka Svípjóðar, og Seðlabanka Bandaríkjanna frá miðjum síðasta áratug, eru dæmi um slíkar nefndir. Í opinberri umræðu geta nefndarmenn í nefndum af pessu tagi jafnvel lýst ólíkum skoðunum sínum og gert t.d. markaðsaðilum pað ljóst að nefndin er ekki ætíð einhuga um ákvarðanir í peningamálum. Í pessu samhengi nefnir Sibert (2006) að peningastefnunefnd Englandsbanka

peningamálum p.á m. um viðskipti við lánastofnanir önnur en prautavaralán, bindiskyldu og viðskipti á gjaldeyrismarkaði (sjá nánar í 24. grein laga nr. 36/2001 um Seðlabanka Íslands). 
sé dæmi um hvernig hægt sé að komast hjá hugsanlegum vanda tengdum hóphugsun. Par eru nefndarmenn hvattir til pess að taka einstaklingsbundna afstöðu auk pess sem gagnsæið sem ríkir um ákvarðanatökuna í formi fundargerða og opinberrar birtingar á atkvæðum nefndarmanna skapar utanaðkomandi aðhald.

Hins vegar eru nefndir par sem lögð er áhersla á að eining ríki um ákvörðunina, a.m.k. opinberlega, og peningastefnunefndin stendur öll að baki ákvörðuninni (e. collegial committees). Formleg atkvæðagreiðsla fer ekki alltaf fram og ekki er skýrt opinberlega frá pví hvernig atkvæði féllu pegar pað gerist. Seðlabanki Evrópu (ECB) og peningastefnunefnd Seðlabanka Noregs eru dæmi um slíkt fyrirkomulag. Í slíkum nefndum getur staða seðlabankastjóra sem formanns nefndarinnar verið ólík eftir pví á hvaða hátt samstaða næst. Hún getur verið afar sterk á pann hátt að bankastjórinn sé nánast einráđur um stefnuna og ætlast sé til að aðrir nefndarmenn fylgi honum. Dæmi um slíka nefnd er peningastefnunefnd Seðlabanka Bandaríkjanna pegar Alan Greenspan var seðlabankastjóri. Á hinn bóginn getur verið að nefndarmenn skiptist á skoðunum á bak við luktar dyr og hafi pannig áhrif á ákvörðunina en séu síðan á endanum samhljóma um niðurstöðuna pegar hún er tilkynnt og í opinberri umræðu. ECB er dæmi um slíkt fyrirkomulag (Blinder, 2007). ${ }^{4}$

En hvernig uppbygging peningastefnunefnda hentar best? Blinder (2007) komst að peirri niðurstöðu að nefnd par sem nefndarmenn greiða atkvæði byggt á eigin skoðunum sé líklega best til pess fallin að nýta pá eiginleika sem nefndarfyrirkomulag hefur umfram pað pegar einstaklingur tekur ákvarðanir. Hann nefndi pó að helsti ókosturinn væru hugsanleg vandkvæði tengd pví ef nefndin væri í sumum tilfellum afar ósamstíga og lýsti ólíkum skoðunum opinberlega en pað gæti dregið úr skýrleika skilaboða nefndarinnar og flækt umræðuna um peningastefnuna í stað pess að útskýra rökin fyrir tilteknum ákvörðunum. Samkvæmt Maier (2010) er heppilegasta fyrirkomulagið í raun pað sem endurspeglar báða kosti ofangreindra aðferða p.e. peningastefnunefnd par sem einstaklingar greiða atkvæði byggt á eigin sannfæringu og skoðunum en að hún sé pó nægjanlega samstíga og öguð til að skilaboðin séu bæði skýr og gagnsæ.

Gerlach-Kristen (2005) skoðar hvort hætta sé á að peningastefnunefndir sem leggja áherslu á að ná fram einingu um ákvörðunina bregðist of seint og of lítið við breyttum aðstæðum í efnahagslífinu. Niðurstöður hennar benda til pess að í peim nefndum par sem niðurstöður fást með meirihluta atkvæða sé brugðist hraðar við breyttum aðstæðum í pjóðarbúskapnum en í nefndum par sem samstaða um ákvörðunina parf að nást. Nefndir par sem reynt er að ná fram samstöðu eru einnig ólíklegri til að breyta vöxtum en breyta peim hins vegar í stærri skrefum en nefndir par sem ákvarðanir eru teknar með einföldum meirihluta.

Könnun sem var gerð á viðhorfum núverandi og fyrrverandi nefndarmanna peningastefnunefnda Seðlabanka Svípjóðar og Noregs til ýmissa pátta í tengslum við störf og skipan nefndanna bregður frekara ljósi á kosti og galla ólíkra leiða til að taka ákvarðanir í peningamálum (Apel o.fl., 2013). Báðir seðlabankar starfa á grundvelli verðbólgumarkmiðs en skipan og starfshættir peningastefnunefndanna eru hins vegar nokkuð ólík. ${ }^{5}$ Ýmsar

\footnotetext{
${ }^{4}$ Annars konar fyrirkomulag er tilfelli Seðlabanka Nýja-Sjálands en par er einn seðlabankastjóri en peningastefnunefnd veitir bankastjóranum ráðgjöf hvað varðar mótun og framkvæmd peningastefnunnar. Nefndin hefur hins vegar ekki lögbundið ákvörðunarvald.

${ }^{5}$ Peningastefnunefnd Seðlabanka Svípjóðar samanstendur af sex nefndarmönnum sem eru allir starfsmenn bankans. Nefndin leggur ekki áherslu á að ná fram einingu um vaxtaákvörðunina sem fæst með atkvæðagreiðslu par sem hver nefndarmaður er ábyrgur fyrir sínu atkvæði. Niðurstöðurnar eru birtar opinberlega í fundargerðum. Peningastefnunefnd Noregsbanka samanstendur af sjö
} 
niðurstöður könnunarinnar staðfestu pað sem fyrri rannsóknir höfðu leitt í ljós, t.d. að pátttakendur töldu að ákvarðanir í peningamálum ættu fremur að vera í höndum nefndar heldur en eins einstaklings en að nefndin ætti ekki að vera of fjölmenn. Einnig bentu niðurstöðurnar til pess að bankastjórinn sem formaður nefndarinnar hefði meiri áhrif pegar nefndin væri af peim toga að áhersla væri lögð á að eining ríkti opinberlega um ákvörðunina. Hins vegar virtust svarendur frekar styðja pað fyrirkomulag sem tíðkaðist í peirri peningastefnunefnd sem viðkomandi starfaði í, en pað bendir til pess að í pessum efnum sé ekki til staðar hið eina rétta fyrirkomulag. Svarendur voru t.d. almennt ósammála um mikilvægi pess að hafa utanaðkomandi sérfræðinga í nefndinni, hvort birta ætti ítarlegar fundargerðir eða hvernig best væri að ræða aðgerðir í peningamálum opinberlega. pví er áhugavert að fjalla nánar um nokkra pætti sem geta verið ólíkir pvert á peningastefnunefndir.

\subsection{Samsetning peningastefnunefnda}

Nokkuð algengt er að peningastefnunefndir séu samsettar af bæði starfsmönnum seðlabankans (innri nefndarmenn) og sérfræðingum utan bankans (ytri nefndarmenn). Peir síðarnefndu eru pá yfirleitt utanaðkomandi sérfræðingar í peninga- og pjóðhagfræði eða á öðrum sviðum sem tengjast viðfangsefni peningastefnunefndarinnar. Eins og Blinder (2009) bendir á er ekki augljóst hvaða samsetning hentar best en pó auki fjölbreytni innan nefndarinnar líkur á að ólík sjónarmið séu tekin til skoðunar. Hann telur heppilegasta fyrirkomulagið vera að meirihluti nefndarinnar samanstandi af sérfræðingum í peningahagfræði en að innri nefndarmenn séu ekki endilega í meirihluta. ${ }^{6}$ Í sumum seðlabönkum, t.d. Englandsbanka, hafa einstaklingar með starfsreynslu úr einkageiranum einnig verið nefndarmenn í peningastefnunefndinni.

Maier (2010) fjallar m.a. um samsetningu og skipulag peningastefnunefnda í rannsókn sinni á peningastefnunefndum í ólíkum löndum. Að hans mati getur samsetning nefndarinnar og skipulag peningastefnufunda haft áhrif á bæði niðurstöður fundanna og gæði ákvörðunartökunnar. Umbætur á ákvörðunarferlinu gætu haft sams konar áhrif og pegar gagnsæi í störfum seðlabanka er aukið, p.e. leitt til pess að peningastefnan verði fyrirsjáanlegri. Ef seðlabankar fylgja peim fordæmum sem hafa gefist best á alpjóðlegum vettvangi varðandi umgjörð peningastefnunnar getur pað jafnframt leitt til betri kjölfestu verðbólguvæntinga. Varðandi samsetningu nefndarinnar tiltekur Maier að ein leið til pess að koma í veg fyrir hjarðhegðun nefndarmanna væri að forðast einsleitni í vali á nefndarmönnum. Nefnd sem samanstendur t.d. eingöngu af starfsmönnum seðlabanka væri líklegri til að vera með einsleitar áherslur og skoðanir heldur en nefnd sem væri fjölbreyttari. Pessu tengt er skipulag vaxtaákvörðunarfunda, t.d. í hvaða röð nefndarmenn fjalla um skoðanir sínar eða greiða atkvæði. Hætta er á að ef t.d. seðlabankastjórinn byrjar ávallt á pví að lýsa afstöðu sinni hafi pað áhrif á aðra nefndarmenn sem forðast hugsanlega að láta í ljós að peir séu ósammála, samanber peningastefnunefnd Seðlabanka Bandaríkjanna pegar Alan Greenspan var seðlabankastjóri. Maier nefnir pví að mikilvægt sé að nefndarmenn séu hvattir til pess að viðhafa sjálfstæð vinnubrögð í pessum efnum. Einnig gæti verið skynsamlegt að skipulag fundarins feli í sér að nefndarmenn greiði ekki alltaf atkvæði í sömu röð.

nefndarmönnum, tveimur innri nefndarmönnum og fimm ytri nefndarmönnum. Áhersla er lögð á að eining ríki um ákvörðunina og stendur nefndin í heild sinni að baki henni.

6 Blinder leggur einnig áherslu á að ekki sé heppilegt að stjórnmálamenn eða fulltrúar stjórnmálaafla séu í peningastefnunefnd par sem pað geti grafið undan sjálfstæði peningastefnunnar og trúverðugleika hennar. 


\subsection{Stærð peningastefnunefnda}

Ýmsar rannsóknir hafa verið gerðar á pví hver sé heppilegasta stærð peningastefnunefnda. Sibert (2006) kemst að peirri niðurstöðu að heppilegasti fjöldi nefndarmanna sé u.p.b. fimm og að líklegt sé að fjölmennari nefndir séu ekki eins skilvirkar. Rannsóknir hennar benda til pess að um leið og nefndarmönnum fjölgi umfram sjö til níu sé hætta á að dragi úr pátttöku einstakra nefndarmanna og að gagnkvæm samskipti gangi verr í hópum með fleiri en tólf nefndarmönnum.7 Í samantekt Maier (2010) kemur fram að algengasti fjöldi nefndarmanna í peningastefnunefndum sé á bilinu fimm til tíu. Niðurstöður hans benda til pess að pví fleiri sem sitja í nefndinni pví meiri líkur séu á að nefndarmaður víki sér undan ábyrgð par sem pað verður ekki eins augljóst ef tiltekinn einstaklingur tekur ekki pátt í ákvörðuninni eða undirbýr sig ekki fyrir fundi. Að sama skapi benda niðurstöður Erhart o.fl. (2007) til pess að verðbólga sé jafnan sveiflukenndari í löndum par sem nefndarmenn eru færri en fimm.

\section{Nýr rammi peningastefnunnar á Íslandi}

\subsection{Breytingar á ramma peningastefnunnar i kjölfar fjármálakreppunnar}

Snemma árs 2009 voru gerðar grundvallarbreytingar á umgjörð peningastefnunnar hér á landi og núverandi skipan yfirstjórnar peningamála komið á fót. Lögum um Seðlabanka Íslands var breytt á pann veg að mótun peningastefnunnar og ákvarðanir um beitingu stjórntækja Seðlabankans yrðu framvegis í höndum sérstakrar peningastefnunefndar sem væri skipuð fimm nefndarmönnum í stað priggja manna bankastjórnar áður. Nefndin skal skipuð premur fulltrúum frá Seðlabankanum, p.e. bankastjóra, aðstoðarbankastjóra og einum af yfirmönnum bankans á sviði stefnumótunar í peningamálum, og tveimur utanaðkomandi sérfræðingum á sviði efnahags- og peningamála. ${ }^{\circledR}$ Seðlabankastjóri er formaður nefndarinnar. Við breytinguna á umgjörð peningastefnunnar var alpjóðleg reynsla af fyrirkomulagi ákvörðunartöku í peningamálum höfð til hliðsjónar. Leitast var við að tryggja að skipan og starfshættir peningastefnunefndarinnar væru í takt við niðurstöður rannsókna um hvernig best sé að móta rammann í kringum ákvörðunarvald í peningamálum. Breytingin miðaði einnig að pví að styrkja enn frekar faglegan grundvöll ákvarðana Seðlabankans í peningamálum.

Breytingarnar á skipan yfirstjórnar peningamála komu í kjölfar fjármálaáfallsins haustið 2008 pegar ríflega níu tíundu af bankakerfi Íslendinga fóru í prot á sama tíma og alpjóðleg fjármálakreppa reið yfir (sjá umfjöllun í Bjarni G. Einarsson o.fl., 2015). Reynslan af fjármálakreppunni benti til pess að skjóta pyrfti sterkari stoðum undir ákvarðanir í peningamálum og efnahagsstefnuna almennt. Árangur Seðlabankans í viðureigninni við verðbólgu hafði par að auki verið tiltölulega slakur stóran hluta tímabilsins frá pví að verðbólgumarkmiðið var tekið upp á árinu 2001 og pangað til að fjármálakreppan skall á árið 2008. Eins og fjallað hefur verið um í ritum Seðlabankans eru margvíslegar ástæður taldar vera

7 Peningastefnunefndir Seðlabanka Bandaríkjanna og ECB eru nokkru stærri eða 15 manna í Bandaríkjunum og 25 manna í ECB (6 nefndarmenn í framkvæmdastjórn auk seðlabankastjóra peirra 19 landa sem hafa tekið upp evruna). Í báðum tilfellum greiða hins vegar ekki allir nefndarmenn atkvæði á öllum vaxtaákvörðunarfundum heldur er notast við kerfi par sem atkvæðarétturinn færist milli hluta nefndarmanna í tiltekinni röð (e. rotation system).

${ }^{8}$ Ráðherra (nú fjármála- og efnahagsráðherra) skipar seðlabankastjóra og aðstoðarseðlabankastjóra til fimm ára í senn að undangengnu hæfnismati priggja manna matsnefndar. Ráðherra skipar einnig utanaðkomandi sérfræðingana tvo til fimm ára í senn. Seðlabankastjóri er síðan sá sem skipar einn af yfirmönnum bankans á sviði stefnumótunar í peningamálum. 
fyrir pessu, p.á m. alpjóðlegar aðstæður lausafjárgnóttar og lágra vaxta, hnökrar í miðlunarferli peningastefnunnar og misbrestir í framkvæmd hennar og óhagstætt samspil stefnunnar í peningamálum og fjármálastefnu hins opinbera. Petta átti sinn pátt í pví að ekki tókst að tryggja peningastefnunni nægilegan trúverðugleika og skapa verðbólguvæntingum kjölfestu í verðbólgumarkmiðinu (Seðlabanki Íslands, 2010, 2012). Pví pótti mikilvægt að breytt skipan peningamála tæki tillit til sjónarmiða um að auka trúverðugleika peningastefnunnar og um leið tryggja enn frekar sjálfstæði Seðlabankans.

\subsection{Fyrirkomulag vaxtaákvarðana}

Núverandi lög kveða á um að peningastefnunefnd haldi fundi að minnsta kosti átta sinnum á ári og að ákvarðanir nefndarinnar grundvallist á vönduðu mati á ástandi og horfum í efnahags- og peningamálum og fjármálastöðugleika. Lögin kveða einnig á um að nefndin setji sér starfsreglur um undirbúning, rökstuðning og kynningu ákvarðana sinna í peningamálum. Fyrir hverja vaxtaákvörðun eru haldnir ítarlegir 1-2 daga fundir par sem sérfræðingar innan Seðlabankans kynna nýlega próun og horfur í efnahagsmálum og á fjármálamörkuðum fyrir nefndinni ásamt sérstökum viðfangsefnum pegar pað á við. Stundum er einnig kallað eftir utanaðkomandi kynningum á ýmsum málum sem eru til skoðunar innan nefndarinnar. Markmiðið er að öll sjónarmið komist að og að tryggt sé að ákvarðanir séu byggðar á faglegum og traustum grunni og eins gagnsæjar og fyrirsjáanlegar og raunhæft er. Starfshættir nefndarinnar að pví er varðar vaxtaákvörðunina hafa próast á tímabilinu frá pví að hún hóf störf. Í meginatriðum fela peir í sér að seðlabankastjóri geri tillögu um vaxtaákvörðun sem hann telur að nái meirihluta eftir að hafa hlýtt á afstöðu hinna nefndarmannanna. Atkvæðagreiðsla um tillöguna fer síðan fram og ræður meirihluti atkvæða niðurstöðunni. Skipulag fundarins felur jafnframt í sér að nefndarmenn lýsi ekki ávallt afstöðu sinni eða greiði atkvæði í sömu röð. Starfsháttum peningastefnunefndarinnar svipar pví til pess fyrirkomulags sem er við lýði í t.d. Englandsbanka og Seðlabanka Svípjóðar.

\subsection{Miðlun upplýsinga um ákvarðanir peningastefnunefndar}

Núverandi lög kveða á um að fundargerðir peningastefnunefndar séu birtar opinberlega tveimur vikum eftir hverja vaxtaákvörðun og par gerð grein fyrir ákvörðunum nefndarinnar og forsendum peirra. Par koma m.a. fram pær upplýsingar sem sérfræðingar bankans kynntu fyrir nefndinni um próun og horfur í efnahagsmálum og pau sjónarmið sem komu fram meðal nefndarmanna á fundinum. Jafnframt er greint frá pví hver tillaga seðlabankastjóra var, viðbrögð og rökstuðningur nefndarmanna og endanleg ákvörðun nefndarinnar. Í Ársskýrslu Seðlabankans er síðan greint frá pví hvernig einstakir nefndarmenn greiddu atkvæði á liðnu ári. Nefndarmönnum gefst einnig tækifæri til pess að láta í ljós pá skoðun sína að pótt peir fallist á að greiða atkvæði með tillögu seðlabankastjóra hefðu peir kosið aðra ákvörðun en telji muninn vera pað lítinn að viðkomandi geti fallist á tillögu bankastjóra. Í fundargerð kemur síðan fram ef einhver nefndarmaður var pessarar skoðunar og hvað hann hefði fremur kosið að gera. Peningastefnunefnd skal einnig gefa Alpingi skýrslu um störf sín tvisvar á ári og ræða efni skýrslunnar í peirri pingnefnd sem pingforseti ákveður.

Nokkuð misjafnt er eftir löndum hvort atkvæðagreiðslur séu nafngreindar. Fyrirkomulagið hér á landi pekkist ekki í öðrum löndum en markmiðið er að tryggja sem mest gagnsæi í ákvarðanatöku og ábyrgð einstakra nefndarmanna á eigin ákvörðunum en pó á pann hátt að ákveðin fjarlægð væri á milli einstakra vaxtaákvarðana og birtingar upplýsinga um afstöðu einstakra nefndarmanna t.d. í tengslum við fjölmiðlaumfjöllun um viðkomandi fundi. Fyrirkomulagið tekur pví tillit til beggja sjónarmiða. Í flestum seðlabönkum sem eru 
með peningastefnunefnd af svipuðum toga og Seðlabanki Íslands (p.e. ákvörðun tekin með meirihluta atkvæða) eru atkvæði einstakra nefndarmanna kunngjörð í fundargerðum t.d. hjá Englandsbanka og seðlabönkum Bandaríkjanna og Svípjóðar.

\subsection{Breytingunum fylgdi aukið gagnsæi}

Birting fundargerða sem innihalda upplýsingar um hvað kom fram á fundunum, vægi ólíkra sjónarmiða og atkvæðagreiðslu nefndarmanna var afar mikilvægt skref og jók gagnsæi peningastefnunnar til muna. Sama á við um reglubundna og aukna upplýsingagjöf til Alpingis og aukin samskipti á vettvangi pingnefndarfunda par sem tækifæri skapast fyrir nefndarmenn peningastefnunefndarinnar til að svara spurningum er varða störf og ákvarðanir nefndarinnar (einnig sett í lög 2009). Dincer og Eichengreen (2014) hafa mælt gagnsæi og sjálfstæði seðlabanka ríflega 100 landa og skoðað hvernig próunin hefur verið á undanförnum árum. Niðurstöður peirra sýna að gagnsæi jókst hjá langflestum seðlabönkum á tímabilinu 19982010. ${ }^{9}$ Sú niðurstaða nær til próaðra ríkja, nýmarkaðsríkja og próunarlanda. Alpjóðlega fjármálakreppan virðist ekki hafa snúið við peirri próun. Meginástæðu aukins gagnsæis telja pau vera að pað sé árangursrík leið til pess að efla trúverðugleika seðlabanka og skuldbindinga peirra. Skuldbinding um að tryggja litla og stöðuga verðbólgu verður meira sannfærandi ef seðlabanki útskýrir nákvæmlega hvernig ákvarðanir hans leiða til pess að markmiðum bankans verði náð. Jafnframt gefur trúverðug skuldbinding seðlabankanum meira rými til pess að víkja frá hefðbundinni peningastefnu við skilyrði óhefðbundinna aðstæðna par sem almenningur, fyrirtæki og markaðsaðilar myndu vita að frávikið væri tímabundið og ekki á skjön við langtímamarkmið bankans. Niðurstöður Dincer og Eichengreen sýna einnig að sjálfstæði seðlabanka í heiminum hefur almennt aukist á tímabilinu. Rannsókn peirra staðfestir að sjálfstæði og gagnsæi seðlabanka eru nátengdir pættir á pann hátt að sjálfstæði gefur seðlabönkum svigrúm til pess að framkvæma stefnu sína en gagnsæi gerir peim kleift að útskýra stefnuna fyrir markaðsaðilum sem um leið gerir alla ákvörðunartöku skilvirkari.

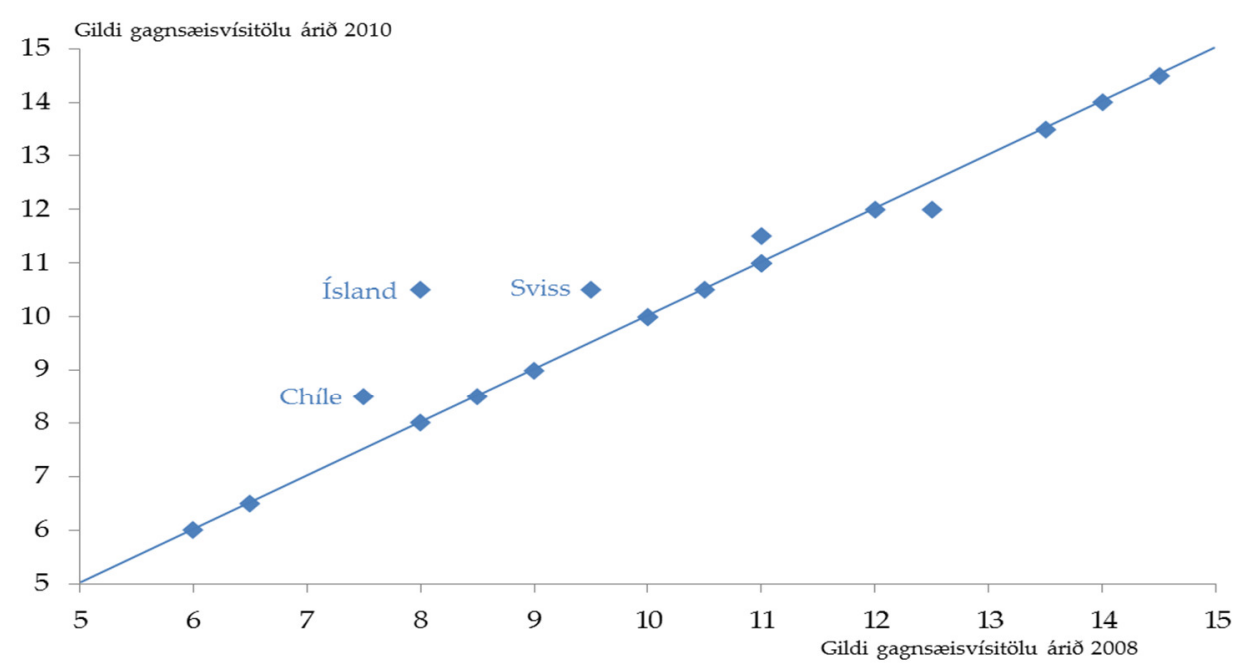

Mynd 1. Gagnsæi seðlabanka 2008 og 2010

Visitalan byggistá 15 spurningum er lúta aơ gagnsæi markmiơs peningastefnunnar, efnahagslegum forsendum ákvörơunartöku, hvernig ákvörơunartakan fer fram, tilkynningum um vaxtaákvarđanir og ađ hvađa leyti seőlabankar gera grein fyrir árangri peningastefnunnar. Heimild:
Dincer og Eichengreen (2014).

9 Útreikningarnir byggjast á spurningum er lúta að gagnsæi markmiðs peningastefnunnar, efnahagslegum forsendum ákvörðunartöku, hvernig ákvörðunartakan fer fram, tilkynningum um vaxtaákvarðanir og að hvaða leyti seðlabankar gera grein fyrir árangri peningastefnunnar. 


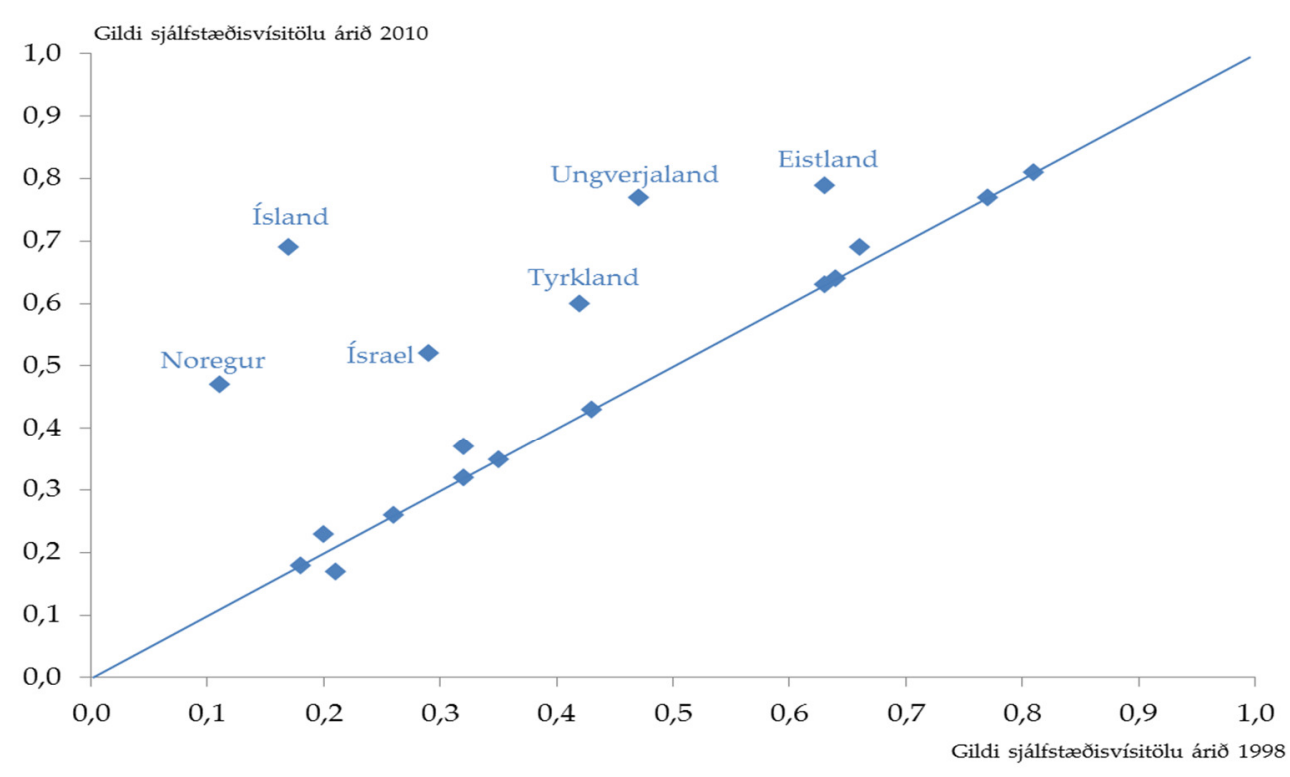

Mynd 2. Sjálfstæði seðlabanka 1998 og 2010

Vísitalan byggistá lagalegri umgiörŏ seđlabanka, t.d. hvað varđarar skipan seơlabankastióra framkvæma peningastefnunnar, markmið seơlabanka, möguleika ríkisstjórna til fjármögnunar hjá seőlabönkum og skipan bankaráóa. Heimild: Dincer og Eichengreen (2014).

Samkvæmt mælikvarða Dincer og Eichengreen jókst gagnsæi Seðlabanka Íslands verulega á tímabilinu 1998-2010 og náði meðaltali OECD-ríkjanna á árinu 2009.10 Gagnsæi seðlabanka hafði jafnframt aukist mest á Íslandi ef litið er til próunarinnar í kjölfar alpjóðlegu fjármálakreppunnar og var Seðlabankinn í 11.-13. sæti árið 2010 ásamt seðlabönkum Japan og Sviss (af OECD-ríkjunum). Peir seðlabankar par sem peningastefnan er hvað gagnsæjust eru Seðlabankar Nýja-Sjálands og Svípjóðar par sem rík hefð hefur myndast um að stefna peirra og vinnubrögð séu afar gagnsæ. Breytingarnar á ramma og umgjörð peningastefnunnar hér á landi árið 2009 pýddu pví að tekin voru stór skref í átt að meira gagnsæi auk pess sem pær færðu peningastefnuna nær peirri umgjörð sem gengur og gerist í samanburðarlöndum okkar.

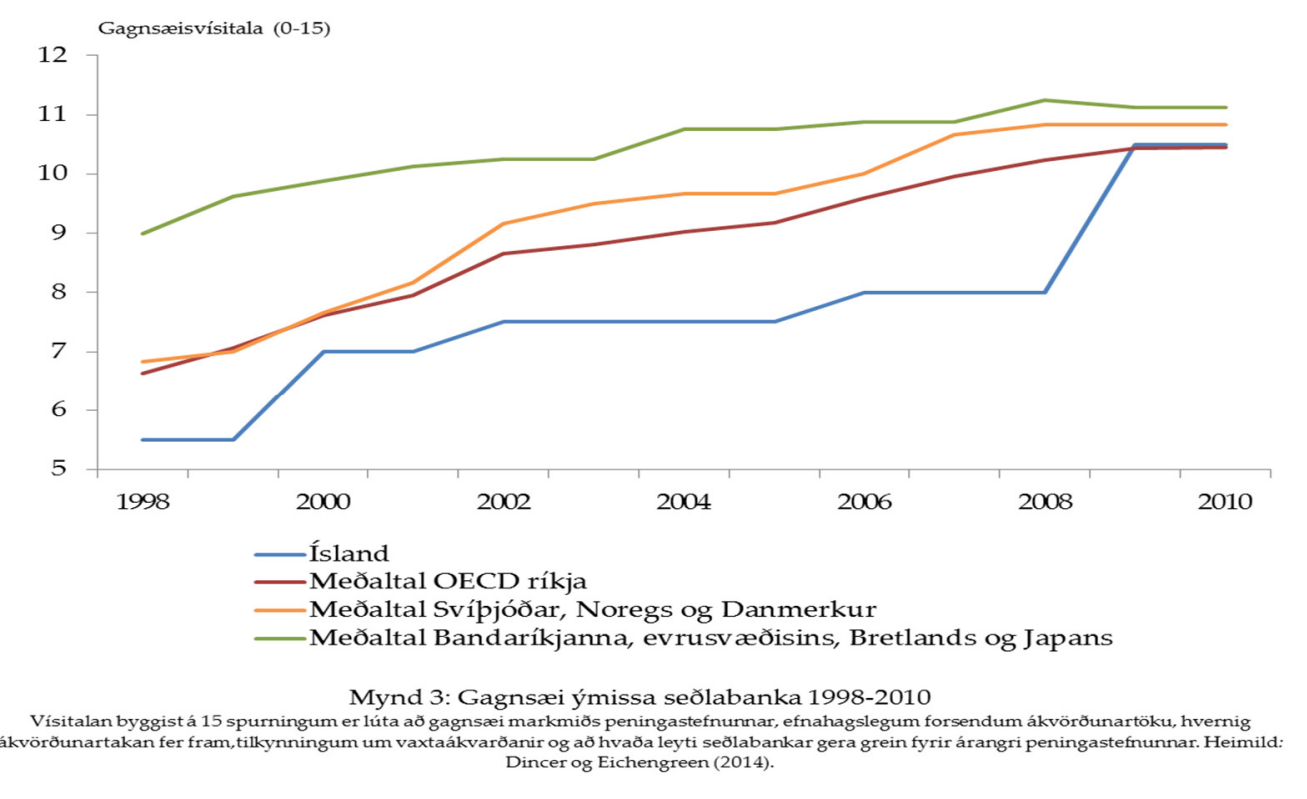

10 Sjá einnig umfjöllun um alpjóðlega próun í átt að auknu sjálfstæði og gagnsæi við stjórn peningamála og stöðu mála hér á landi í alpjóðlegum samanburði um síðustu aldamót í grein Pórarins G. Péturssonar (2000). 
Crowe og Meade (2008) skoðuðu hvernig sjálfstæði seðlabanka hefði próast síðan í lok níunda áratugarins og sýndu niðurstöður peirra að pað hefði almennt aukist, mest í próunarog nýmarkaðsríkjum. Pau skoðuðu einnig hvernig gagnsæi seðlabanka hefði próast frá lokum tíunda áratugarins og fundu einungis marktæka aukningu hjá próuðum ríkjum en ekki öllu úrtakinu. Niðurstöðurnar bentu einnig til pess að marktæk fylgni væri á milli aukningar í sjálfstæði seðlabanka og minni verðbólgu.

\section{Atkvæðagreiðslur peningastefnunefndar Seðlabankans}

Á tímabilinu 2009-2015 hélt peningastefnunefnd Seðlabankans 57 vaxtaákvörðunarfundi. Í rúmlega helmingi tilvika kaus nefndin að halda vöxtum óbreyttum, í 30\% tilvika voru vextir lækkaðir en í 16\% tilvika voru peir hækkaðir. Nefndin hefur pví lækkað vexti tvöfalt oftar en hún hefur hækkað pá á pessu sjö ára tímabili sem hún hefur starfað.

\subsection{Samhljóða ákvörðun í liðlega helmingi tilvika}

Oftast var ágreiningur um ákvörðunina árið 2012 eða í 3/4 tilvika og litlu færri árið 2009 eða í 2/3 tilvika. Að jafnaði var meiri ágreiningur um ákvörðunina pegar vextir voru hækkaðir heldur en pegar peir voru lækkaðir. Pað voru 9 vaxtahækkanir á árunum 2009-2015, par af voru prjú skipti par sem einn nefndarmaður vildi heldur halda vöxtum óbreyttum og síðan fjögur skipti par sem einn nefndarmaður vildi hækka vexti um meira en ákveðið var að gera. Sjaldnast var ósamstaða árið 2013 pegar vöxtum var haldið óbreyttum allt árið. Einungis á einum fundi á pví ári var ágreiningur um ákvörðunina. Niðurstöður atkvæðagreiðslna yfir allt tímabilið sýna að ekki náðist full samstaða í hátt í helmingi atkvæðagreiðslna og að í priðjungi tilvika greiddi einn nefndarmaður atkvæði gegn meirihlutanum og í 14\% tilvika voru tveir nefndarmenn í minnihluta. Pví er ljóst að ólík sjónarmið hafa verið til staðar innan nefndarinnar sl. sjö ár enda er markmiðið með fjölskipaðri peningastefnunefnd einmitt að ólík sjónarmið takist á sem eykur líkurnar á að tekin sé upplýst ákvörðun.

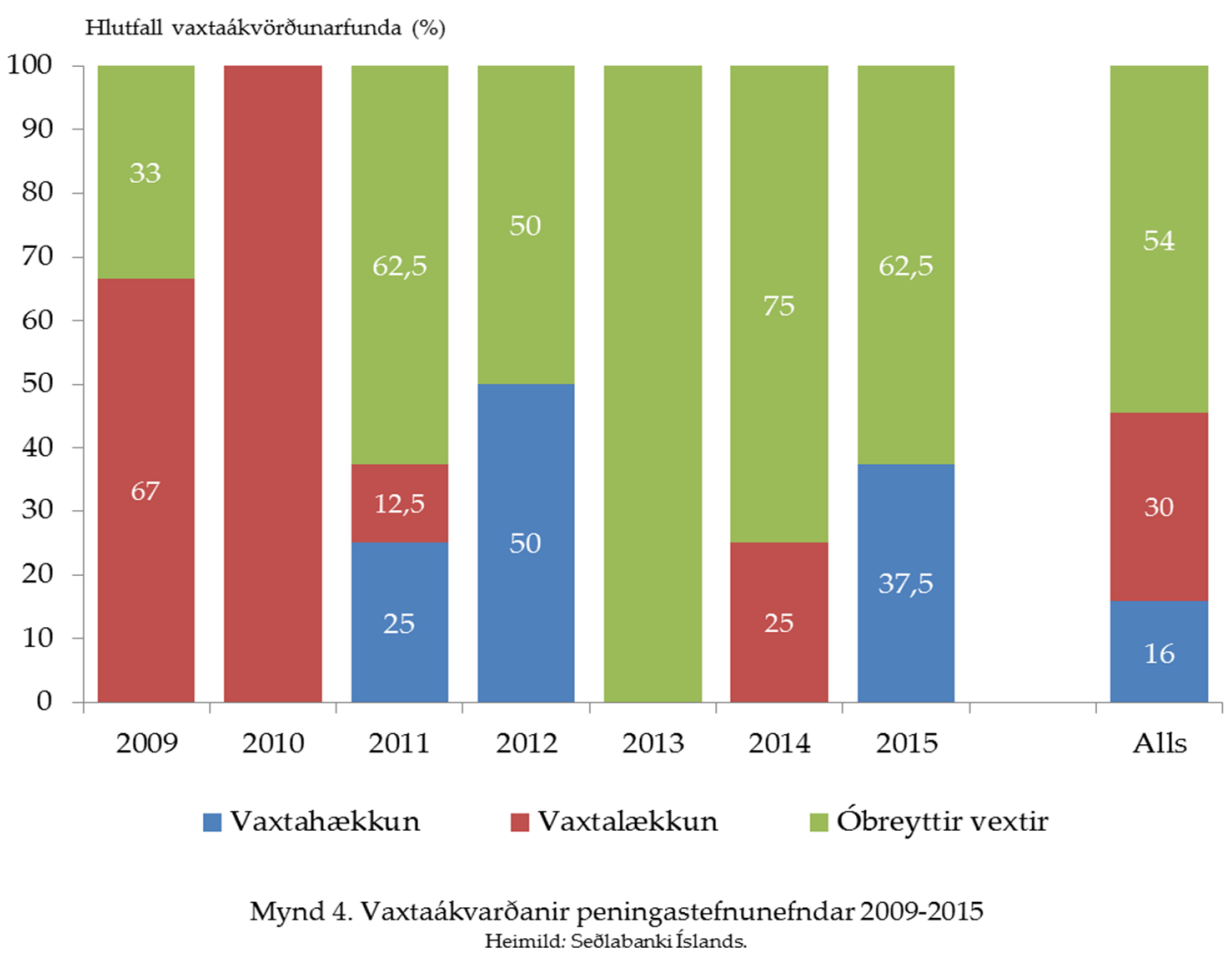




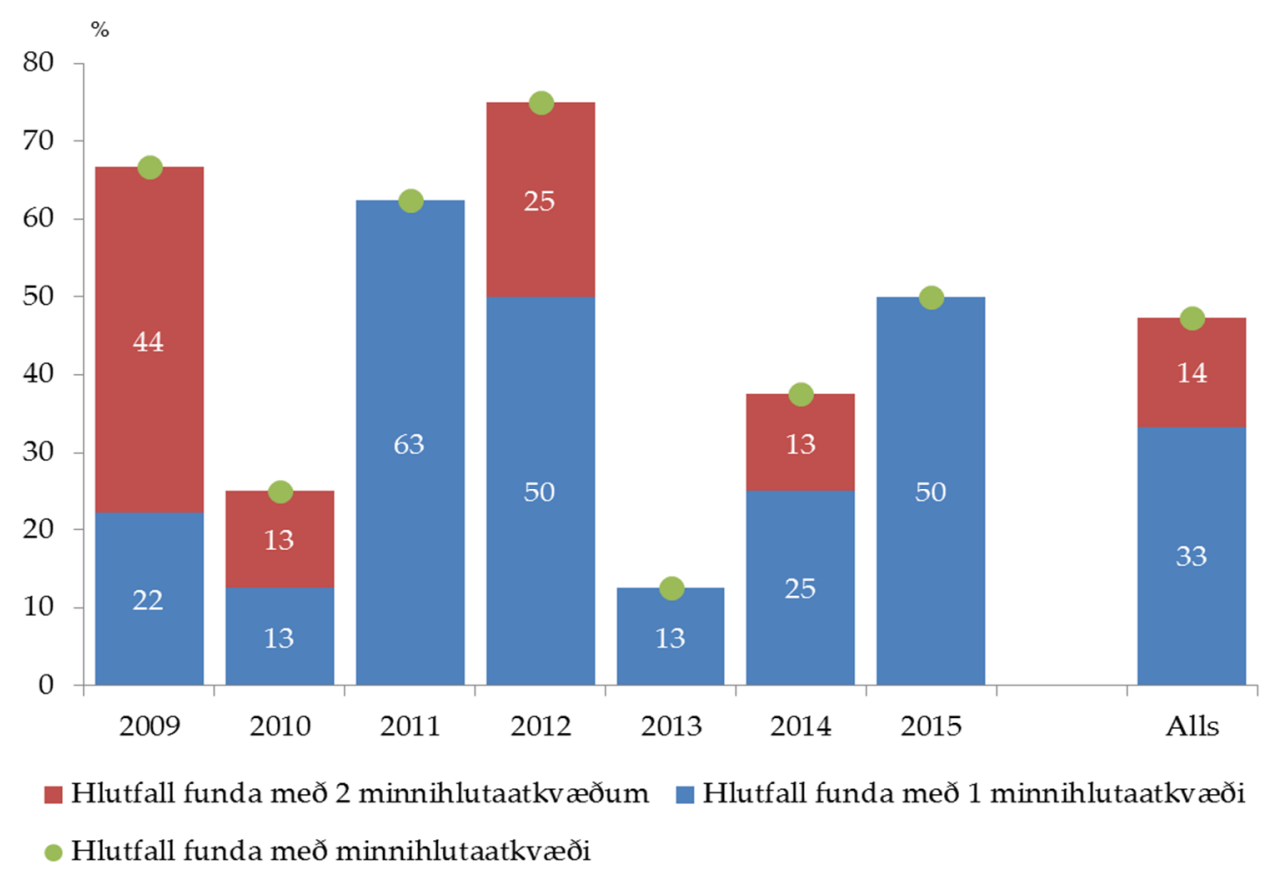

Mynd 5. Meðalfjöldi minnihlutaatkvæða í peningastefnunefnd 2009-2015. Heimild: Seðlabanki Islands.

\subsection{Samsetning minnihlutans hefur verið breytileg}

Ef minnihlutaatkvæðin eru skoðuð nánar kemur íljós að Anne Sibert, sem var annar af tveimur utanaðkomandi sérfræðingum í nefndinni frá febrúar 2009 til febrúar 2012, og Pórarinn G. Pétursson aðalhagfræðingur Seðlabankans hafa oftast verið í minnihluta eða í 30\% tilvika. Í $12 \%$ tilvika hefur innri nefndarmaður verið í minnihluta en ytri nefndarmaður í 13\% tilvika. Már Guðmundsson seðlabankastjóri hefur einu sinni verið í minnihluta og Arnór Sighvatsson aðstoðarseðlabankastjóri prisvar. Pá hefur ytri nefndarmaður ekki verið í minnihluta síðan í nóvember 2012 pegar vaxtahækkunartímabilinu sem hófst rúmlega ári áđur lauk. Í öllum atkvæðagreiðslum nefndarinnar um vaxtaákvarðanir síðan pá (til loka ársins 2015) hafa pví Gylfi Zoëga og Katrín Ólafsdóttir tilheyrt meirihlutanum. Pegar ágreiningur hefur verið í nefndinni samanstendur meirihlutinn oftar af bæði innri og ytri nefndarmönnum heldur en eingöngu innri nefndarmönnum. Í pau skipti par sem tveir nefndarmenn hafa verið í minnihluta hafa innri nefndarmenn myndað meirihluta í fjórðungi tilvika.

Pegar tveir nefndarmenn hafa greitt atkvæði gegn tillögu seðlabankastjóra hefur samsetning minnihlutans pví verið nokkuð breytileg. Pórarinn G. Pétursson og Anne Sibert voru prisvar saman í minnihluta, á tveimur fundum á vaxtalækkunartímabilinu 2009-2010 og aftur pegar vaxtahækkunarferlið var hafið í byrjun ársins 2012. Рað hefur einungis tvisvar gerst á tímabilinu að utanaðkomandi nefndarmenn hafi verið saman í minnihluta og pað var á fyrsta starfsári nefndarinnar árið 2009. Innri nefndarmenn hafa prisvar verið saman í minnihluta, annars vegar pegar Már Guðmundsson og Arnór Sighvatsson voru í minnihluta haustið 2009 og vildu pá lækka vexti fremur en að halda peim óbreyttum og hins vegar pegar Arnór Sighvatsson og Pórarinn G. Pétursson voru saman í minnihluta haustið 2012 og aftur í lok árs 2014. Í fyrra skiptið vildu peir fremur halda áfram að hækka vexti heldur en hafa pá óbreytta í kjölfar pess að nefndin hafði hækkað vexti fyrr á árinu. Í seinna skiptið voru vextir 
lækkaðir en peir vildu lækka pá um minna en ákveðið var að gera. Innri nefndarmenn hafa pví afar sjaldan myndað priggja-manna meirihluta á móti ytri nefndarmönnum á tímabilinu auk pess sem staða seðlabankastjóra lítur ekki út fyrir að vera of ráðandi miðað við tíð minnihlutaatkvæði annarra innri nefndarmanna.

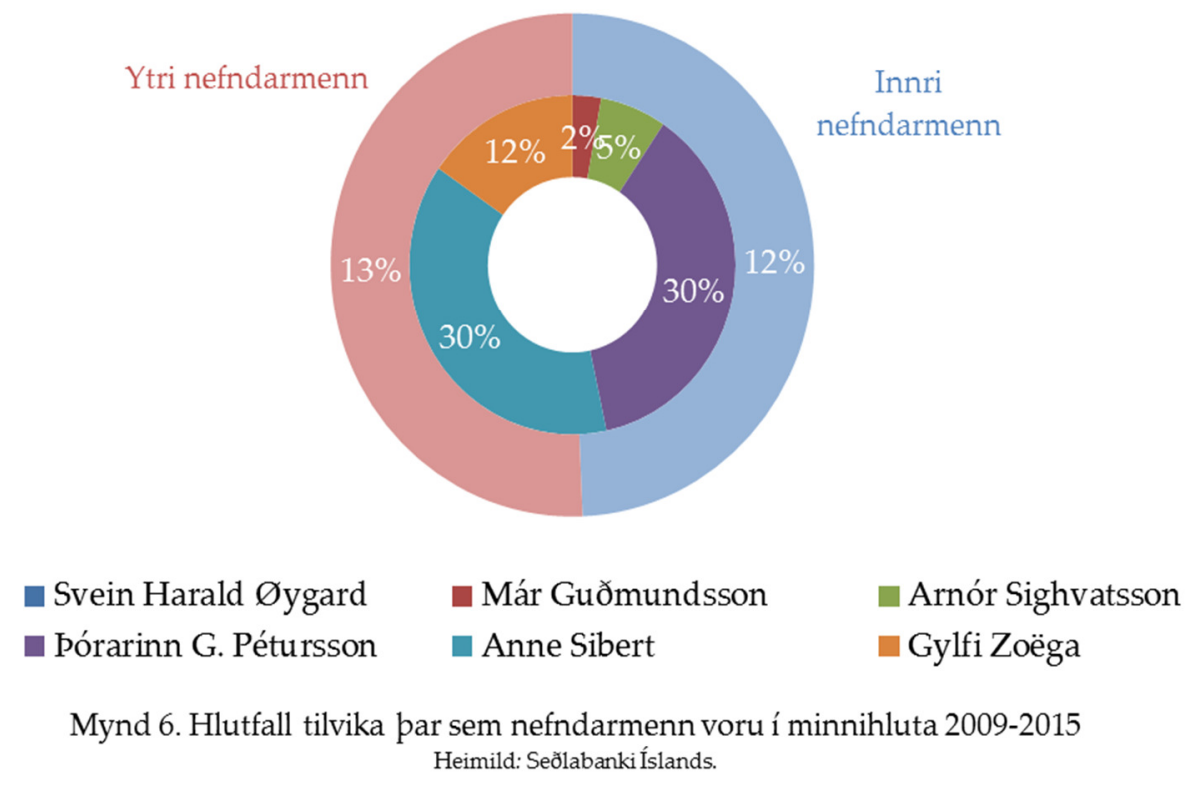

\subsection{Innri nefndarmenn virðast oftar kjósa harðara taumhald heldur en lausara}

Pegar um var að ræða vaxtaákvörðunarfundi par sem ekki var eining innan nefndarinnar um ákvörðunina kaus minnihlutinn oftar harðara taumhald peningastefnunnar en veikara. Í 3/4 peirra tilvika par sem ekki náðist samstaða á fundum kaus minnihlutinn harðara taumhald en tillaga seðlabankastjóra hljóðaði upp á. Oftast gerðist petta á árinu 2012 eða á fimm fundum, pegar meðalverðbólga á árinu nam 5,2\% eftir að hafa aukist hratt á árinu 2011. Á árinu 2015 voru jafnframt fjórir fundir par sem minnihlutinn kaus harðara taumhald en ákveðið var en meðalverðbólga á árinu nam 1,6\%. Pá voru hins vegar horfur á vaxandi verðbólguprýstingi í kjölfar kjarasamninganna vorið 2015. Рað var pví einungis í fjórðungi peirra tilvika par sem ekki náðist samstaða um vaxtaákvörðun eða á sjö fundum, sem minnihlutinn greiddi atkvæði með veikara taumhaldi en ákveðið var. Рað gerðist á premur fundum árið 2009 á fyrsta starfsári nefndarinnar pegar innlend eftirspurn tók að dragast saman í kjölfar fjármálaáfallsins og verðbólga tók að hjaðna. Hins vegar gerðist pað einnig á premur fundum árið 2011 pegar efnahagsbatinn var hafinn og verðbólga var á uppleið og aftur í lok ársins 2012 pegar vaxtahækkunartímabilinu lauk. Pað virðist pví vera samband á milli frávika verðbólgu frá verðbólgumarkmiðinu og óeiningar innan nefndarinnar: eftir pví sem verðbólga víkur meira frá markmiði eru meiri líkur á að ósamstaða ríki um vaxtaákvarðanir.

Hins vegar virðist vera nokkur munur á kosningahegðun innri og ytri nefndarmanna pegar minnihlutaatkvæðin eru skoðuð nánar. Pegar innri nefndarmenn voru í minnihluta kusu peir oftar hærri vexti en tillaga seðlabankastjóra hljóðaði upp á heldur en lægri vexti. •að 
sama á ekki við um ytri nefndarmennina par sem fjöldi minnihlutaatkvæða peirra skiptist jafnt milli pess að vilja hærri eða lægri vexti en meirihlutinn kaus. Innri nefndarmenn virðast pví almennt kjósa meira taumhald peningastefnunnar heldur en peir ytri. Jafnframt eru vísbendingar um að innri nefndarmenn bregðist af meiri krafti við versnandi verðbólguhorfum en ytri nefndarmenn. Í u.p.b. helmingi tilvika par sem vaxtaákvörðunarfundur var á sama tíma og verðbólguspá sem sýndi versnandi verðbólguhorfur á spátímabilinu var birt samhliða í Peningamálum, var innri nefndarmaður í minnihluta vegna pess að hann kaus harðara taumhald en var ákveðið á fundunum. Í tilfelli ytri nefndarmanna var sama uppi á teningnum í tæplega 30\% tilvika.

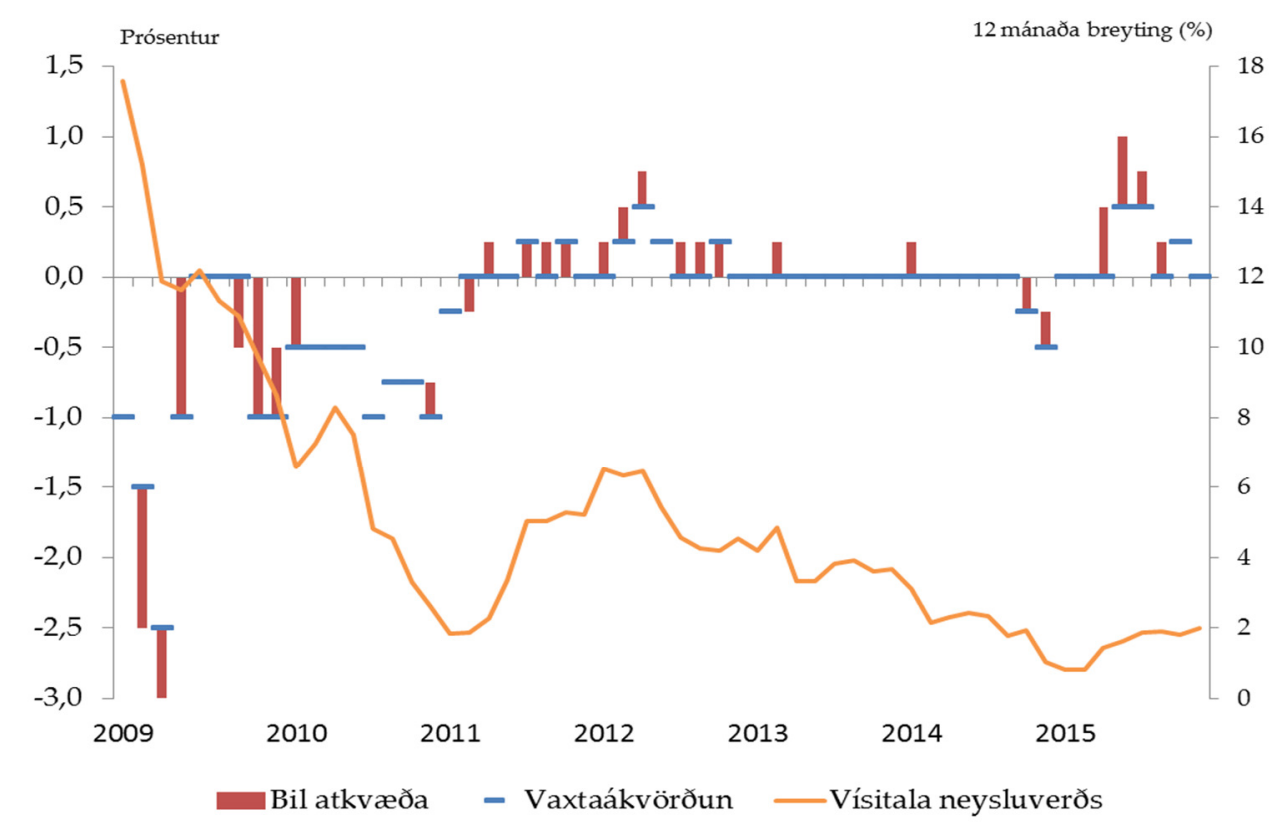

Mynd 7. Atkvæðagreiðslur peningastefnunefndar og verðbólga 2009-2015 Súlur sýna á hvaõa bili atkvæơin voru. Ef pađ er engin súla pá var peningastefnunefndin einhuga. Heimildir: Hagstofa Íslands, Seơlabanki Íslands.

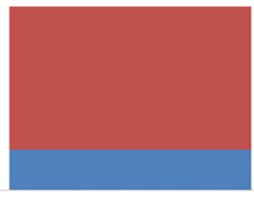

Kaus lægri vexti

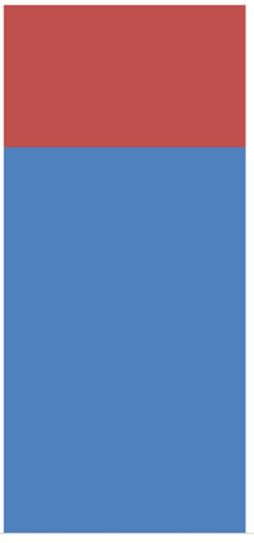

Kaus hærri vexti

Innri meðlimir $\square$ Ytri meðlimir 
Samstaða var pó á meðal innri nefndarmannanna um vaxtalækkun í rúmlega 70\% tilvika par sem vextir voru lækkaðir en peir voru sammála um vaxtahækkun í 56\% tilvika par sem vextir voru hækkaðir. Í peim tilvikum par sem innri nefndarmenn voru ekki sammála um vaxtahækkunina var ástæðan sú að einn af peim vildi hækka vexti um meira en ákveðið var að gera.

\subsection{Oftar samstaða um óbreytta vexti en pegar ákveðið var að breyta vöxtum}

Almennt var meiri samhljómur í nefndinni pegar ákveðið var að halda vöxtum óbreyttum en ef átti að breyta peim. Samstaða var á meðal nefndarmanna í tæplega $2 / 3$ tilvika par sem vöxtum var haldið óbreyttum en í um 38\% tilvika par sem vöxtum var breytt, par af var einhuga ákvörðun í tæplega helmingi tilvika vaxtalækkana en í rúmlega fimmtungi tilvika hækkana. Í peim tilfellum par sem ekki náðist samstaða um ákvörðunina um að halda vöxtum óbreyttum var oftast einn nefndarmaður mótfallinn ákvörðuninni eða í átta skipti. Рað var einungis á premur fundum par sem tveir nefndarmenn greiddu atkvæði gegn pví að halda vöxtum óbreyttum, par af tvisvar árið 2012 pegar minnihlutinn vildi frekar hækka vexti. Athygli vekur einnig að pað hefur aldrei gerst að tveir nefndarmenn hafi greitt atkvæði gegn hækkun vaxta. Hins vegar hefur pað gerst álíka oft að priggja manna meirihluti náði saman um vaxtalækkun eins og fjögurra manna meirihluti. Pað er pví athyglisvert að prátt fyrir að á heildina litið hafi mun oftar náðst full samstaða innan nefndarinnar um vaxtalækkun heldur en vaxtahækkun, hafi aldrei verið fleiri en einn nefndarmaður í minnihluta pegar um var að ræða vaxtahækkun. Jafnframt hefur sú staða ekki komið upp að minnihlutinn hafi greitt atkvæði með hækkun vaxta pegar ákveðið var að lækka vexti eða öfugt.

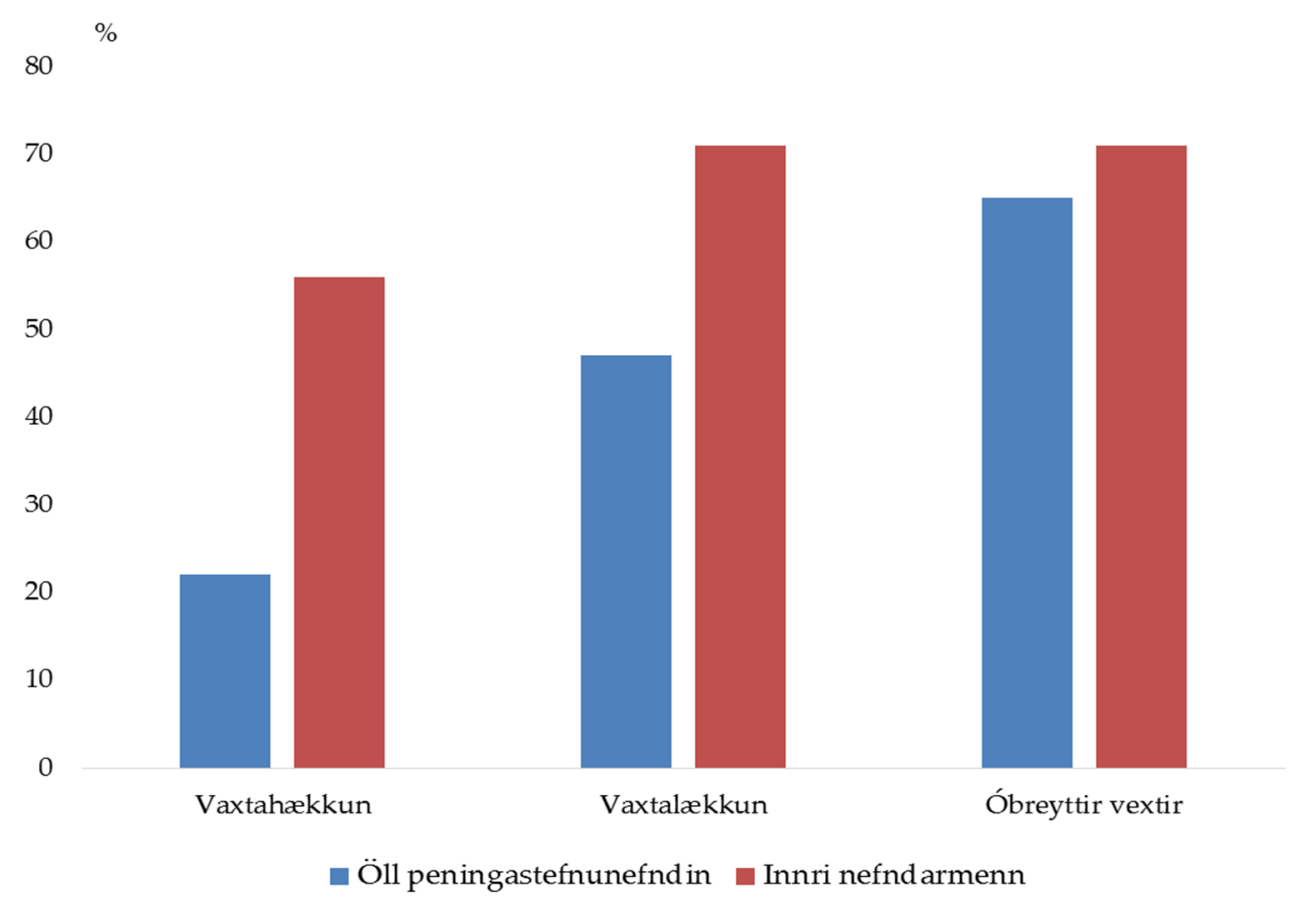

Mynd 9. Hlutfall tilvika par sem nefndarmenn voru einhuga um vaxtaákvarðanir Heimild: Seðlabanki Íslands. 


\section{Alpjóðlegur samanburður}

Atkvæðaskipting peningastefnunefndar Seðlabanka Íslands undanfarin sjö ár virðist vera í ágætu samræmi við pað sem tíðkast erlendis meðal seðlabanka með svipað ákvarðanaferli. Í ræðu sem páverandi seðlabankastjóri Englandsbanka, Mervyn King, hélt árið 2007 um tíu ára reynslu peningastefnunefndar bankans fjallaði hann um ólíkar skoðanir nefndarmanna á ákvörðunum um peningastefnuna og taldi pær endurspegla ólík sjónarmið um pað hvernig ætti að túlka gögn um próun efnahagsmála. Stundum hefði staðan í efnahagsmálum verið afar óljós og túlkun haggagna pví erfið sem leiddi til eðlilegra skoðanaskipta og ólíkra sjónarmiða innan nefndarinnar og p.a.l. aukins fjölda vaxtaákvörðunarfunda par sem ekki náðist samhljómur um niðurstöðuna. Á hinn bóginn gat sú staða verið uppi að staða hagsveiflunnar og eðli efnahagsskella voru óumdeild og nauðsynleg viðbrögð við peim skýr og pví komu tímabil par sem allir í nefndinni voru sammála um aðgerðir í peningamálum. Í ræðu King kemur einnig fram að minnihlutaatkvæði eru töluvert fleiri hjá peningastefnunefnd Englandsbanka heldur en t.d. í peningastefnunefndum seðlabanka Bandaríkjanna, Svípjóðar og Japans og sama má segja um hlutfall funda par sem a.m.k. fjórðungur nefndarmanna er í minnihluta. Samanburður á atkvæðamynstrinu hér á landi við upplýsingar sem parna koma fram bendir til pess að hlutfallsleg tíðni tilvika hér á landi par sem einn nefndarmaður er í minnihluta sé svipuð og var í Svípjóð á árunum 1999-2007 en um helmingi lægri en í Bretlandi á sama tímabili. Hins vegar er hlutfall tilvika par sem a.m.k. fjórðungur nefndarmanna er í minnihluta heldur lægra hér en í Bretlandi en aftur á móti nokkru hærra en í Svípjóð. Jafnframt er meðalfjöldi nefndarmanna sem er í minnihluta heldur hærri hér en í Bandaríkjunum og Svípjóð en lægri en í Bretlandi.

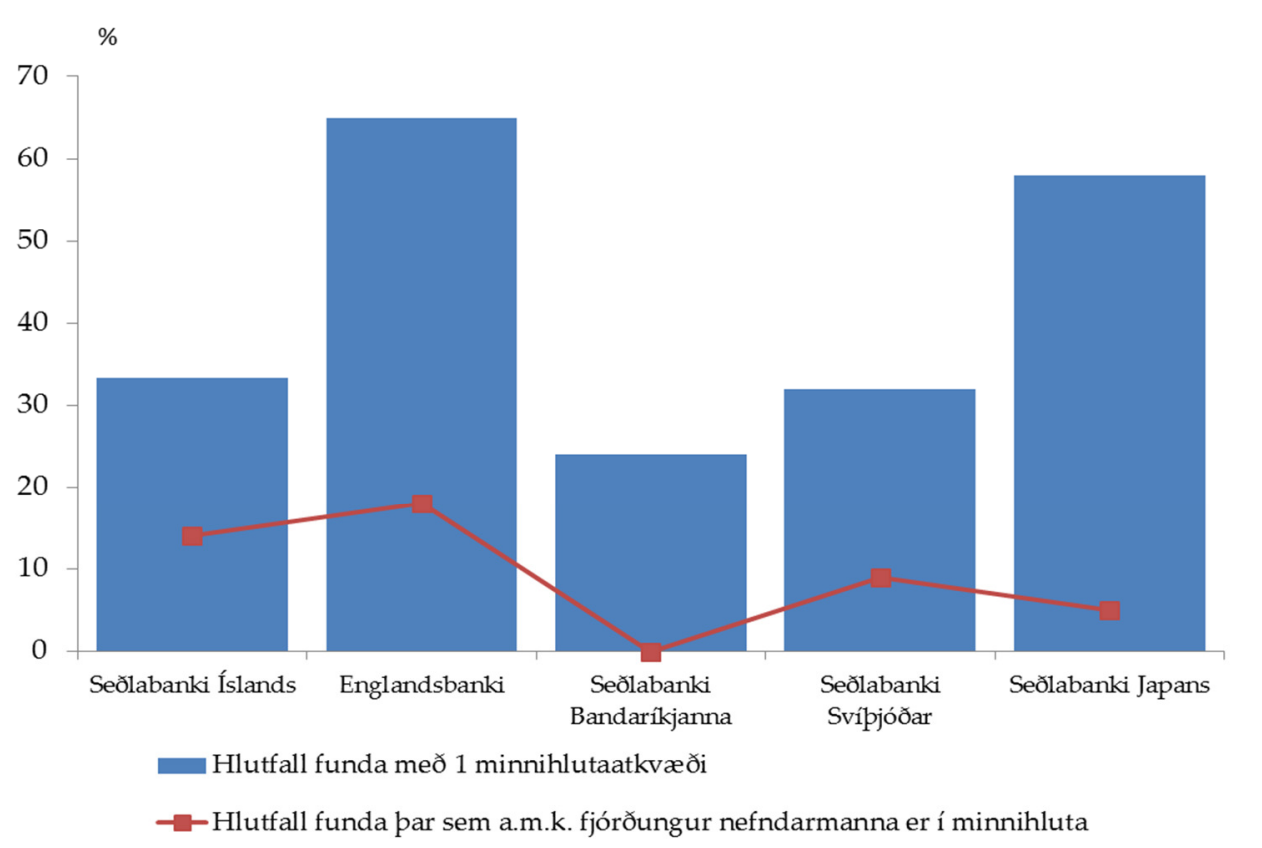

Mynd 10. Vísbendingar um óeiningu í peningastefnunefndum nokkurra seðlabanka Byggt á eftirfarandi tímabilum: 1997-2007 hjá Englandsbanka, 1997-2007 hjá peningastefnunefnd seðlabanka Bandaríkjanna og 1999-2007 hjá peningastefnunefnd seðlabanka Svípjóðar. Heimildir: Englandsbanki, Seđ̆labanki Bandaríkjanna, Seơlabanki Svípjóðar, Seð̋labanki Íslands. 
Niðurstöður rannsóknar Gerlach-Kristen (2009) á atkvæðamynstri peningastefnunefndar Englandsbanka benda jafnframt til pess að ytri nefndarmenn hafi tilhneigingu til að kjósa lægri vexti en innri nefndarmenn, líkt og er raunin hér á landi eins og áður var rakið, einkum á samdráttartímabilum. Ólíkt pví sem virðist vera hér á landi eru ytri nefndarmenn hins vegar oftar í minnihluta í Englandsbanka heldur en peir innri. Hún telur líklegar ástæður fyrir pví vera m.a. að ytri nefndarmenn virðast leggja meiri áherslu á að forðast samdrátt í efnahagslífinu heldur en innri nefndarmenn (e. recession averse). Ólík tapföll (e. loss function) nefndarmanna gætu pví skýrt mun á atkvæðamynstri peirra og hugsanlegt væri að innri nefndarmenn legðu meiri áherslu á verðstöðugleika en peir ytri.

Pessar niðurstöður ríma vel við niðurstöður rannsóknar Hansen og McMahon (2008) á atkvæðagreiðslum peningastefnunefndar Englandsbanka sem benda til pess að ástæðan fyrir pví að ytri nefndarmenn hafi tilhneigingu til að kjósa lægri vexti sé ekki sú að peir hafi ólíkan bakgrunn eða reynslu heldur einfaldlega staða peirra sem utanaðkomandi nefndarmenn. Hugsanlega sé pví eitthvað innbyggt í stofnanaumgjörðina sem valdi ólíkri kosningahegðun. Niðurstaða peirra bendir til pess að skipun utanaðkomandi nefndarmanna breyti atkvæðamynstri nefndarinnar ekki ein og sér heldur geti skipt máli hvort viðkomandi nefndarmenn fái um leið stjórnunarstöður innan seðlabankans og eigi möguleika á starfsframa par. Peir nefna að t.d. sé grundvallarmunur á stöðu ytri nefndarmanna í Englandsbanka annars vegar og í Seðlabanka Svípjóðar hins vegar. Pegar ytri nefndarmenn eru skipaðir í peningastefnunefnd Seðlabanka Svípjóðar verða peir um leið hluti af starfsliði bankans sem er ólíkt umgjörðinni í Englandsbanka. Niðurstöður peirra benda einnig til pess að munur á kosningahegðun sé eingöngu bundinn við nefndarmenn sem höfðu verið í nefndinni lengur en eitt ár. Í upphafi virðist ekki marktækur munur á atkvæðamynstri nefndarmanna en pegar líður á tímabilið fara ytri nefndarmenn að kjósa lægri vexti en innri nefndarmenn.

Niðurstöður rannsóknar Jung (2011) á atkvæðamynstri nokkurra peningastefnunefnda benda til pess að innri nefndarmenn peningastefnunefndar Englandsbanka bregðist af meiri krafti við hættu á aukinni verðbólgu í kjölfar efnahagslegra áfalla heldur en ytri nefndarmenn sem er svipað og virðist vera raunin hér á landi. Niðurstöður Berk, Bierut og Meade (2010) eru af svipuðum toga og benda til pess að enginn munur sé á atkvæðamynstri innri og ytri nefndarmanna peningastefnunefndar Englandsbanka á fyrsta ári peirra í nefndinni. Pegar komið er á priðja ár í nefndarstörfum virðast innri nefndarmenn frekar kjósa hærri vexti og leggja meiri áherslu á verðstöðugleika og minni áherslu á framleiðsluslaka en ytri nefndarmenn.

\section{Lokaorð}

Peningastefnunefnd Seðlabanka Íslands hefur tekið ákvarðanir um beitingu stjórntækja Seðlabanka Íslands í peningamálum síðan snemma árs 2009. Peningastefnunefndir geta verið af ólíkum toga og var alpjóðleg reynsla af fyrirkomulagi ákvörðunartöku í peningamálum höfð til hliðsjónar pegar nefndinni var komið á fót hér og leitast við að skipan nefndarinnar og starfshættir væru í takt við pað hvernig best sé að móta umgjörð í kringum ákvörðunarvald í peningamálum. Breytingin var einnig til pess gerð að auka gagnsæi peningastefnunnar og festa sjálfstæði Seðlabanka Íslands enn frekar í sessi.

Atkvæðagreiðslur peningastefnunefndar á tímabilinu 2009-2015 sýna að engar vísbendingar eru um blokkamyndanir innan nefndarinnar. Niðurstöðurnar sýna að ekki náðist full samstaða í hátt í helmingi atkvæðagreiðslna og að í priðjungi tilvika greiddi einn 
nefndarmaður atkvæði gegn meirihlutanum og í tæplega sjöttungi tilvika voru tveir nefndarmenn í minnihluta. Ólík sjónarmið hafa pví verið til staðar innan nefndarinnar sl. sjö ár enda er markmiðið með fjölskipaðri peningastefnunefnd að ólíkar skoðanir takist á sem eykur líkurnar á að tekin sé upplýst ákvörðun. Pegar um er að ræða ágreining í nefndinni samanstendur meirihlutinn oftar af bæði innri og ytri nefndarmönnum en eingöngu innri nefndarmönnum. Í pau skipti par sem tveir nefndarmenn eru í minnihluta hafa innri nefndarmenn eingöngu myndað meirihluta í fjórðungi tilvika. Samsetning minnihlutans hefur pví verið nokkuð breytileg á tímabilinu. Hins vegar virðist vera munur á kosningahegðun innri og ytri nefndarmanna pegar minnihlutaatkvæðin eru skoðuð nánar. Pegar innri nefndarmenn voru í minnihluta kusu peir oftar hærri vexti en tillaga seðlabankastjóra hljóðaði upp á heldur en lægri vexti. Рað sama á ekki við um ytri nefndarmennina par sem fjöldi minnihlutaatkvæða peirra skiptist jafnt milli pess að vilja hærri eða lægri vexti en meirihlutinn kaus. Atkvæðaskipting peningastefnunefndar og munur á kosningahegðun innri og ytri nefndarmanna virðist einnig hafa verið svipuð pví sem tíðkast í nágrannalöndum okkar sem eru með sams konar fyrirkomulag.

Verðbólga hefur verið undir verðbólgumarkmiði bankans um tveggja og hálfs árs skeið sem er lengsta tímabil par sem verðbólga er við eða undir markmiði frá pví að verðbólgumarkmiðið var innleitt árið 2001. Hagvöxtur hefur sótt í sig veðrið undanfarin misseri og kröftugur bati átt sér stað á innlendum vinnumarkaði. Langtímaverðbólguvæntingar hafa pokast niður á við og eru vísbendingar um að árangur peningastefnunnar undanfarin ár hafi skapað verðbólguvæntingum traustari kjölfestu en áður. Líklegt er að aukið gagnsæi um ákvarðanir tengdar peningastefnunni í kjölfar pess að peningastefnunefnd hóf störf hafi aukið trúverðugleika Seðlabankans og pannig leitt til væntinga um minni verðbólgu. Próunin á næstu árum á pó eftir að leiða í ljós hversu traust kjölfesta peirra reynist.

\section{Heimildir}

Alpingi, 2001. Lög um Seðlabanka Íslands. Slóðin er http://www.althingi.is/lagas/nuna/2001036.html

Alpingi, 2009. Frumvarp til laga um breytingar á lögum nr. 36/2001, um Seðlabanka Íslands. Slóðin er http://www.althingi.is/altext/136/s/0506.html

Apel, M., C. A. Claussen, P. Gerlach-Kristen, P. Lennartsdotter og Ø. Røisland (2013). Monetary policy decisions - Comparing theory and „inside“ information from MPC members. Norges Bank Working Paper 03/2013.

Berk, J. M., B. Bierut, E. Meade (2010). The dynamic voting patterns of the Bank of England's MPC. De Nederlandsche Bank Working Paper 261/2010.

Bjarni G. Einarsson, Kristófer Gunnlaugsson, Porvarður Tjörvi Ólafsson og Pórarinn G. Pétursson (2015). The long history of financial boom-bust cycles in Iceland - Part I: Financial crises. Seðlabanki Íslands, Working Papers, nr. 68.

Blinder, A. S., (2007). Monetary policy by committee: Why and how? European Journal of Political Economy, 23, 106-123.

Blinder, A. S., (2009). Making monetary policy by committee. International Finance, 12, 171-194.

Blinder, A. S., og J. Morgan (2005). Are two heads better than one? Monetary policy by committee. Journal of Money, Credit, and Banking, 37, 789-812. 
Blinder, A. S., og J. Morgan (2008a). Do monetary policy committees need leaders? A report on an experiment. American Economic Review, 98, 224-229.

Blinder, A. S., og J. Morgan (2008b). Leadership in groups: A monetary policy experiment. International Journal of Central Banking, 4, 117-150.

Crowe, C., og E. Meade (2008). Central bank independence and transparency: Evolution and effectiveness. IMF Working Paper, 08/119, International Monetary Fund.

Dincer, N. N., og B. Eichengreen (2014). Central bank transparency and independence: Updates and new measures. International Journal of Central Banking, 10, 189-253.

Erhart, S., H. Lehment og J. Vasquez-Paz (2007). Monetary policy committee size and inflation volatility. Kiel Working Paper, no. 1377. Kiel Institute for the World Economy.

Gerlach-Kristen, P., (2005). Too little, too late: Interest rate setting and the cost of consensus. Economics Letters, 88, 376-381.

Gerlach-Kristen, P., (2009). Outsiders at the Bank of England's MPC. Journal of Money, Credit and Banking, 41, 1099-1115.

Hansen, S., og M. F. McMahon (2008). Delayed doves: MPC voting behaviour of externals. CEP Discussion Paper, no. 862, Centre for Economic Performance.

Jung, A., (2011). An international comparison of voting by committees. European Central Bank Working Paper, no. 1383.

King, M., (2007). The MPC ten years on. Ræða flutt 2. maí 2007.

Lombardelli, C., J. Proudman og J. Talbot (2005). Committees versus individuals: An experimental analysis of monetary policy decision making. International Journal of Central Banking, 1, 181-205.

Maier, P., (2010). How central banks take decisions: An analysis of monetary policy meetings. Í P.L. Siklos, M.T. Bohl og M.E. Wohar (ritstj.), Challenges in Central Banking: The Current Institutional Environment and Forces Affecting Monetary Policy. Cambridge University Press.

Qvigstad, J. F., I. Fridriksson og N. Langbraaten (2013). Monetary policy committees and communication. Staff Memo, no. 2, Norges Bank.

Seðlabanki Íslands (2010). Peningastefnan eftir höft. Sérrit nr. 4.

Seðlabanki Íslands (2012). Valkostir Íslands í gjaldmiðils- og gengismálum. Sérrit nr. 7.

Seðlabanki Íslands. Ársskýrslur fyrir árin 2009-2015.

Sibert, A., (2006). Central banking by committee. International Finance, 9, 145-168.

Pórarinn G. Pétursson (2000). Nýjar áherslur í starfsemi seðlabanka: Aukið sjálfstæði, gagnsæi og reikningsskil gerða. Peningamál, 2000/4. 